\title{
Czasopiśmiennictwo pedagogiczne organizacji nauczycielskich u progu Drugiej Rzeczypospolitej ${ }^{1}$
}

\begin{abstract}
Abstrakt
Zanim Polska odzyskała w 1918 r. niepodległość ważną rolę w rozwoju rodzimych i upowszechnianiu międzynarodowych koncepcji edukacyjnych oraz w projektowaniu rozwiązań dotyczących przyszłego w kraju ustroju szkolnictwa odegrały czasopisma pedagogiczne ukazujące się w okresie pierwszej wojny światowej pod szyldem organizacji nauczycielskich. Należały do nich: „Szkoła”, „Muzeum”, „Ruch Pedagogiczny”, „Wychowanie w Domu i Szkole”, „Przegląd Pedagogiczny”, „Szkoła Polska”, „Miesięcznik Pedagogiczny".
\end{abstract}

Słowa kluczowe: czasopiśmiennictwo pedagogiczne, organizacje nauczycielskie, ziemie polskie, pierwsza wojna światowa.

\section{Pedagogical Journals of Teachers' Organizations at the Threshold of Interwar Poland}

\begin{abstract}
Before Poland regained independence in 1918, a great role in the development of domestic educational concepts and propagation of international ones, as well as in designing solutions concerning the future school system, was played by pedagogical journals published during the Great War by teachers' organizations. They included: "Szkoła" (School), "Muzeum" (Museum), "Ruch Pedagogiczny" (The Pedagogical Movement), "Wychowanie w Domu i Szkole" (Education at Home and at School),

\footnotetext{
* Uniwersytet Łódzki, Katedra Historii Wychowania i Pedeutologii. Artykuł otrzymano: 11.02.2020; akceptacja: 19.03.2020.

1 Praca naukowa finansowana w ramach programu Ministra Nauki i Szkolnictwa Wyższego pod nazwą „Szlakami Polski Niepodległej” w latach 2018-2023; nr projektu: 01SPN 170020 18; kwota finansowania 751222 zł.
} 
"Przegląd Pedagogiczny" (Pedagogical Review), "Szkoła Polska" (Polish School), "Miesięcznik Pedagogiczny" (Pedagogical Monthly).

Keywords: pedagogical journals, teachers' organizations, Polish lands, First World War.

W drugiej połowie XIX i w pierwszych latach wieku XX na ziemiach polskich pod zaborami zasadniczą rolę $\mathrm{w}$ rozwoju i upowszechnianiu myśli edukacyjnej oraz doskonaleniu praktyki szkolnej odgrywały czasopisma pedagogiczne ukazujące się pod szyldem organizacji skupiających w swych szeregach nauczycieli ${ }^{2}$. Po wybuchu pierwszej wojny światowej wszystkich redaktorów tych periodyków, niezależnie od reprezentowanych często odmiennych stanowisk na sprawy polityczne i społeczne, nie tylko łączyła nadzieja na uwolnienie kraju spod krępujących zaborczych ograniczeń, ale myśl, pomimo licznych trudności materialnych i perturbacji organizacyjnych, o konieczności kontynuowania prac edytorskich i ogłaszania drukiem publikacji wpisujących się w ogólnopolską debatę nad przyszłością edukacji publicznej oraz kształtem narodowego szkolnictwa. Atmosferę tamtego okresu najlepiej oddają słowa zamieszczone w lubelskim dwutygodniku adresowanym do nauczycielstwa:

Czas wojny jest przejściowym, przyszłość powojenna nieodgadniona, nieznane losy stwarzanej w chwili obecnej organizacyi wychowawczej. (...) Budujmy więc tak, jakby wojny nie było, myśl o niej niech będzie tylko podnietą do tem większego pośpiechu i ofiarności, by nawet na wypadek runięcia wznoszonego gmachu nasz posiew na niwę ludową wydał już choćby niewielkie plony, by dorzucić do polskiego cywilizacyjnego dorobku wiązkę myśli własnych, by pozostawić po sobie pamięć wielkiego wysiłku i wycisnąć na epoce nowe piękno polskiej wielkości, z którego późniejsze pokolenia czerpałyby wiarę w naród i przyszłość. A przede wszystkiem wierzmy sami, że wznosimy budowę niespożytą, że kładziemy podwaliny nowej Polski i otrząsnąwszy się z przygnębienia i nastrojów wojennych, pracujmy z tą wewnętrzną radością, która jest warunkiem prawdziwego tworzenia (Chwila obecna 1916: 1-2).

Do wydawanych w okresie Wielkiej Wojny czasopism pedagogicznych, które regularnie informowały o sytuacji w szkolnictwie, propagowały najnowsze koncepcje edukacyjne i wychowawcze oraz promowały uznane w Europie projekty dydak-

\footnotetext{
2 W Galicji było to Polskie Towarzystwo Pedagogiczne (od 1868 r.), Towarzystwo Nauczycieli Szkół Wyższych (od 1884 r.) oraz Krajowy Związek Nauczycielstwa Ludowego (od 1905 r.), w Królestwie Polskim - Polski Związek Nauczycielski (od 1905 r.) i Stowarzyszenie Nauczycielstwa Polskiego (od 1905 r.), a po połączeniu w 1917 r. obu ugrupowań w jeden związek: Stowarzyszenie Nauczycielstwa Polskiego oraz powstałe w 1916 r. Zrzeszenie Nauczycielstwa Polskich Szkół Początkowych, a także Polskie Towarzystwo Pedagogiczne w Cieszynie (od 1895 r.). Zob. np. Filipowicz 1986: 39-98.
} 
tyczne, należała lwowska „Szkoła”, którą sygnowało Polskie Towarzystwo Pedagogiczne $^{3}$. Z badań wynika, że redakcja tego miesięcznika, na czele której stał w tym czasie najpierw Jan Kornecki (1914-1915), a następnie Leon Stachoń (1916-1918), regularnie zamieszczała na jego łamach artykuły naukowe z zakresu psychologii i pedologii, pedagogiki, dydaktyki i metodyki, a także historii wychowania oraz higieny szkolnej. Ich autorami najczęściej byli: Henryk Glasgall, Leszek Dziama, Stanisław Jankowski, Józef Kretz (Mirski), Jan Magiera, Antoni Mikulski, Karol Nittmann, Wincenty Sierakowski, Ludwik Skoczylas oraz Jadwiga Strokowa. Natomiast potrzebom odbudowy oświaty narodowej w niepodległym już kraju służyły szkice o stanie i kierunkach zmian w szkolnictwie galicyjskim oraz w pozostałych zaborach, przede wszystkim w Królestwie Polskim ${ }^{4}$, a także instruktywne opracowania, dotyczące odstępowania przez nauczycieli od tradycyjnych zasad, form i metod pracy pedagogicznej i opierania jej na nowatorskich rozwiązaniach naukowych, które respektują i szanują indywidualność wychowanków oraz tworzą sprzyjające warunki do ich rozwoju. Na przykład Ludwik Skoczylas pisał o szczególnej roli w edukacji szkolnej wychowawcy kierującego się w swojej działalności ideami narodowymi (Skoczylas 1914: 309-312, 438-443), Jan Kornecki rozważał o powinnościach społecznych nauczyciela Polaka (Kornecki 1914: 94-96), Julian Buciewicz sformułował wskazówki o praktycznym nauczaniu gospodarstwa domowego dziewcząt w szkołach ludowych wiejskich i małomiasteczkowych (Buciewicz 1914: 133-138), Michał Siciński skoncentrował się na organizacji nauczania w szkołach przemysłowych uzupełniających (Siciński 1914: 122-132), Edward Szajowski omówił memoriał Uniwersytetu Jagiellońskiego dotyczący reformy szkolnictwa (Szajowski 1914: 213-220), Wiktor Brzeziński zaprezentował postulaty w sprawie modernizacji kształcenia w seminariach nauczycielskich (W. B. 1914: 180-185; 234-242).

Warto w tym miejscu zauważyć, że u progu niepodległości Polski redakcja „Szkoły” przywiązywała wielką wagę do informowania czytelników o rozwiąza-

\footnotetext{
3 Inicjatorem i pierwszym redaktorem powstałej w 1868 r. „Szkoły” był Karol Maszkowski, profesor Akademii Technicznej we Lwowie. Czasopismo to jeszcze w tym samym roku odegrało istotną rolę w powołaniu do życia Towarzystwa Pedagogicznego (Zaproszenie 1868: 64), które od 1906 r. funkcjonowało pod nazwą Polskie Towarzystwo Pedagogiczne, które jako współorganizator w 1909 r. drugiego polskiego kongresu pedagogicznego, na który przybyli wybitni przedstawiciele galicyjskich nauk o wychowaniu oraz nauczyciele wszystkich szczebli kształcenia, a także reprezentanci sfer naukowych i oświatowych z Królestwa Polskiego, przyczyniło się w istotnym stopniu do nakreślenia na kolejne lata kierunków rozwoju narodowej edukacji. Zob. Stopińska-Pająk 1996: 171-174; Przeniosło 2015: 379; Jamrożek 2015: 28-62.

4 Warto w tym miejscu zauważyć, że zainteresowanie redakcji „Szkoły” sprawami oświaty w Królestwie Polskim nasiliło się już po rewolucji 1905 r. Największą jednak liczbę artykułów na ten temat publikowano w latach 1916-1918. Zapewne fakt ten pozostawał w związku z dynamicznie rozwijającymi się kontaktami między nauczycielami obu zaborów oraz przygotowywanymi przez działaczy oświatowych Królestwa Polskiego projektami przyszłej organizacji szkolnictwa i kierunku wychowania publicznego w niepodległym już kraju. Zob. np. Stan obecny... 1916: 41-45; Sprawy szkolne... 1916: 45-51; O uniwersytet... 1916: 98; Stachoń 1917: 76-80; Szkolnictwo rolnicze ... 1917: 343; Stan szkolnictwa... 1918: 251-252; Dzieci szkolne... 1918: 250.
} 
niach i projektach edukacyjnych w Królestwie Polskim oraz w wielu państwach europejskich i w Stanach Zjednoczonych, dostrzegając w nich istotne źródło oryginalnych przemyśleń i poczynań dydaktyczno-wychowawczych (Ika 1914-1915: 145-146; Nittman 1914-1915: 317-338, 443-461). Zamieszczano także sprawozdania i oceny nowo wydanych książek pedagogicznych i szkolnych oraz omawiano zawartość aktualnie ukazujących się na ziemiach polskich i poza jej granicami czasopism dla nauczycieli i wychowawców. Przyjęcie takiej perspektywy tworzenia periodyku zaowocowało treściami, które przedstawiały pełny „obraz polskiej oraz zagranicznej myśli pedagogicznej i pracy nauczycielstwa polskiego” ( $Z$ nowym rokiem 1910: 5).

Tak samo ważną rolę $\mathrm{w}$ rozwoju i upowszechnianiu wiedzy z dziedziny nauk o wychowaniu oraz lansowaniu reformatorskich inicjatyw szkolnych, a także raportowaniu o ówczesnej rzeczywistości oświatowej odegrało czasopismo „Muzeum”, które od 1885 r. wydawało we Lwowie Towarzystwo Nauczycieli Szkół Wyższych ${ }^{5}$. Ustosunkowując się do wyzwań, jakie niósł dla Polski światowy konflikt zbrojny, pisano:

Zasadnicze przesilenie wystąpiło również w redakcyi „Muzeum”, która do nowej sytuacyi dostosować się musiała, wiążąc się silniej z chwilą, którą przeżywamy. (...) A „osobliwa” ta chwila, daj Boże, może bardzo niedaleką. To też dziś, stojąc na przełomie, kiedy ustępują dawne formy a wyłaniają się nowe, czujemy głęboko całą powagę chwili obecnej. (...) Pragniemy wszyscy, by minął wreszcie czas, „kiedy szczęścia nie było w ojczyźnie”, a zbliżyła się chwila, kiedy zjednoczenie i samodzielność nasza staną się faktem realnym (Na przełomie... 1916: 1-2).

Po ustąpieniu Bolesława Mańkowskiego z funkcji redaktora ${ }^{6}$ kierownictwo nad pismem objął w 1916 r. Jerzy Dunin-Wąsowicz, bardziej dostosowując je do aktualnych realiów i spodziewanej przyszłości. Z jego inicjatywy do zespołu stałych współpracowników, którzy już wcześniej przedkładali do druku swoje opracowania, dołączyło wielu kolejnych, także pochodzących z Królestwa Polskiego. Wśród nich znajdowali się m.in.: Maksymilian Bienenstock, Stefan Błachowski, Michał Brandstätter, Bogusław Butrymowicz, Albert Halban, Ludwik Jaxa-Bykowski, Juliusz Kleiner, Jan Magiera, Tadeusz Mikułowski, Marian Odrzywolski, Stanisław Turowski, Stanisław Tync, Aniela Szycówna, Mieczysław Ziemnowicz i Zygmunt Ziembiński.

\footnotetext{
5 Towarzystwo Nauczycieli Szkół Wyższych powstało w 1884 r. Po połączeniu w 1919 r. ze Stowarzyszeniem Nauczycielstwa Polskiego z zaboru rosyjskiego przyjęło nazwę Towarzystwo Nauczycieli Szkół Średnich i Wyższych.

6 B. Mańkowski piastował stanowisko redaktora „Muzeum” przez 26 lat i był najdłużej kierującym tym pismem w jego dziejach, które trwale zostały przerwane przez wybuch II wojny światowej. Zob. Szulakiewicz 2013: 108.
} 
Najczęściej poszczególne zeszyty „Muzeum” otwierał dział o charakterze naukowym, przybliżający czytelnikom węzłowe problemy pedagogiczne. Ilustrując szczegółowe orientacje tematyczne z tego zakresu, warto przywołać dociekania kilku autorów. Maksymilian Bienenstock w obszernej rozprawie umieszczonej w kilku kolejnych numerach rozważał problem wychowania estetycznego w świetle teorii Fryderyka Wilhelma Foerstera (Bienenstock 1914: 43-58, 191-197, 352-361), Stanisław Turowski w kilkuczęściowym studium wyjaśniał możliwości wykorzystania w praktyce szkolnej osiągnięć psychologii eksperymentalnej (Turowski 1914: 59-81, 198-217, 361-376, 518-537), Aniela Szycówna pisała o dorobku psychologicznym i pedagogicznym Jana Władysława Dawida (Szycówna 1914-1915: 182-190) oraz omawiała istotę funkcjonowania montessoriańskich domów dziecięcych (Szycówna 1914: 98-105), natomiast Marian Odrzywolski sportretował w oparciu o wyniki badań psychologicznych typy uwagi młodzieży szkolnej (Odrzywolski 1917: 5-28) oraz scharakteryzował znaczenie i ustalił ograniczenia wykorzystania metody eksperymentu w badaniach pedagogicznych (Odrzywolski 1917: 118-130, 185-189).

Zaliczając do jednych z najważniejszych wówczas problemów społecznych zapewnienie sprawnego funkcjonowania szkolnictwa średniego, z jednej strony redaktorzy „Muzeum” wyjaśniali różne szczegółowe kwestie dotyczące kształtu, zadań, organizacji i przebiegu kształcenia w gimnazjach (Halban 1914: 7-20; Wacek 1914-1915: 140-144; Jaxa-Bykowski 1916: 42-46; Kurpiel 1916: 219-229; Hauswald 1917: 317-321), z drugiej natomiast - koncentrowali przekaz wokół zagadnień związanych z niedaleką perspektywą włączenia szkolnictwa galicyjskiego do zunifikowanego dla całego kraju systemu oświatowego. Kontekstami dyskusji w tym przypadku było nie tylko gruntowne zobrazowanie stanu szkolnictwa na terenie Królestwa Polskiego, ale również ukazanie powstających tam projektów nowoczesnego ustroju szkolnego i programów nauczania dla poszczególnych szczebli edukacji (Ruch oświatowy... 1916: 13, 58-60; Chmielewski 1917: 273-275; Feliński 1917: 321-348; Zawiliński 1917: 258-267; Stypiński 1917: 267-273; Kielski B. 1917: 511-525; Ze szkolnictwa... 1917: 559-561).

W każdym zeszycie „Muzeum” znajdowała się ponadto rubryka zatytułowana Oceny i sprawozdania, w której publikowano szerokie omówienia najnowszych wydawnictw, głównie z pedagogiki, dydaktyki i metodyki oraz psychologii, a także recenzje książek $\mathrm{z}$ innych dziedzin nauki, korespondujących merytorycznie z przedmiotami kształcenia w szkole średniej. Podobną postać przyjęła kolumna pod nazwą $Z$ czasopism mająca za zadanie referowanie zawartości kolportowanych na ziemiach polskich periodyków pedagogicznych, a także przybliżanie, w formie obszernych streszczeń, treści wybranych z nich artykułów i rozpraw. Specjalne miejsce zajmowały szpalty przeznaczone na wiadomości bieżące, na których informowano o wydarzeniach naukowych we wszystkich trzech zaborach, aktywności towarzystw pedagogicznych oraz organizacji nauczycielskich i oświatowych, wykładach, odczytach i kursach psychopedagogicznych dla nauczycieli, akcjach 
kolonijnych dla młodzieży, działalności uniwersytetów w Krakowie, Lwowie i Warszawie, kongresach i zjazdach oświatowych.

Niezależnie od „Szkoły” i „Muzeum” - pism o zdecydowanie konserwatywno-narodowym charakterze - w Galicji od 1912 r. ukazywał się ponadto, kierowany przez Henryka Rowida, krakowski miesięcznik „Ruch Pedagogiczny”, którego profil został ukształtowany przez Krajowy Związek Nauczycielstwa Ludowego ${ }^{8}$, organizacji społecznej stawiającej sobie za cel w chwilach „tworzenia się nowego, swobodnego życia na ziemiach polskich" (Nasze dq̨żenia... 1917: 3) modernizację społeczeństwa poprzez upowszechnianie wśród ogółu nowych koncepcji i praktycznych doświadczeń pedagogicznych oraz uchylanie wszelkich barier współpracy w tej dziedzinie z działaczami oświatowymi Królestwa Polskiego (Podgórska 1973: 114-115, 148). Przekazując czytelnikom pierwszy numer periodyku, redakcja w następujący sposób uzasadniała projekt nowego wydawnictwa:

W czasach, kiedy wiedza pedagogiczna, oparta na badaniach, zatacza coraz szersze kręgi, kiedy widzimy wspaniały rozkwit literatury pedagogicznej w Anglii, w Niemczech, Francji, Stanach Zjednoczonych itd., kiedy w krajach cywilizowanych nurtują ożywcze prądy, zmierzające do przeprowadzenia gruntownej reformy wychowania dziecka, zgodnej ze zdobyczami nowoczesnej nauki - jesteśmy świadkami zupełnego niemal zastoju w dziedzinie reform wychowawczych w kraju naszym (Od Redakcyi... 1912: 2).

Dzięki trwale ukształtowanemu schematowi wewnętrznego układu treści, który przetrwał do końca 1918 r., wydawcy tego czasopisma zapewnili w okresie przed odzyskaniem przez Polskę niepodległości jak najszerszą realizację zamierzeń oświatowych nakreślonych w deklaracji programowej. Część pierwszą każdego zeszytu zawsze wypełniało kilkanaście artykułów służących samodoskonaleniu zawodowemu nauczycieli. W jednych popularyzowano wiedzę i osiągnięcia nauk o wychowaniu, przybliżając dokonania badawcze Jana Władysława Dawida w zakresie psychologii i pedagogiki eksperymentalnej, omawiając filozofię wychowania Bronisława Trentowskiego oraz zastanawiając się nad statusem i perspektywami rozwoju pedagogiki naukowej (np. Rowid 1914: 1-9; 1917: 41-47, 65-70,

\footnotetext{
7 Pismo to powstało w 1912 r. Do czasu zawieszenia druku w latach 1915-1916, co spowodowane było trudnościami organizacyjno-finansowymi wywołanymi przez pierwszą wojną światową, na jego łamach zamieszczali swoje artykuły uznani wówczas w Galicji i Królestwie Polskim badacze problemów pedagogicznych i oświatowych, m.in.: Jan Władysław Dawid, Aniela Szycówna, Henryk Rowid, Helena Orsza (Radlińska), Marian Falski, Władysława Weychert-Szymanowska, Anna Grudzińska, Maria Laskowiczówna, Zofia Szybalska. Edycję tego tytułu wznowiono z początkiem 1917 r. i w niezmienionej formie ukazywało się do czasu odzyskania przez Polskę niepodległości.

${ }^{8}$ Krajowy Związek Nauczycielstwa Ludowego powstał w 1905 r. W 1913 r. zmienił nazwę na Związek Polskiego Nauczycielstwa Ludowego. Wieloletnia współpraca tego stowarzyszenia z tożsamymi organizacjami działającymi w Królestwie Polskim, najpierw z Polskim Związkiem Nauczycielskim (1905-1917), a następnie ze Zrzeszeniem Nauczycielstwa Polskich Szkół Początkowych (1916-1919), doprowadziła do powstania jednego ugrupowania: Związku Polskiego Nauczycielstwa Szkół Powszechnych, który od 1930 r. zaczął funkcjonować jako Związek Nauczycielstwa Polskiego.
} 
89-96, 129-135, 153-159, 177-182; Kretz 1918: 173-182), w innych z kolei - pisano o zbliżającej się nowej erze w dziejach szkolnictwa narodowego i w tym kontekście propagowano wprowadzanie w życie innowacyjnych rozwiązań dydaktyczno-metodycznych w nauczaniu różnych przedmiotów oraz w pracy wychowawczej (np. Rowid 1918: 1-9, 12-13, 169-173; Laskowiczówna 1914: 47-52, 65-70; Falski 1917: 49-54, 75-79, 114-120); Witkowska 1917: 183-188; Sławomirski 1918: 118-127).

Niezależnie od obszernych rozpraw naukowych każdy kolejny numer „Ruchu Pedagogicznego" przynosił wyodrębnioną część, w której dogłębnie omawiano aktualną literaturę pedagogiczną oraz zawartość ukazujących się polskich periodyków pedagogicznych i oświatowych, a dzięki kontaktom nawiązanym przez redaktora i jego współpracowników z zagranicznymi ośrodkami myśli naukowej śledzono także obce czasopisma i książkowe nowości poświęcone nowym prądom w wychowaniu (Wojtyński 1965: 22). Zautonomizowaną część stanowił również obszerny dział informujący o szybko rozwijającym się ruchu pedagogicznym we wszystkich polskich dzielnicach, a także poza ich granicami.

W przeciwieństwie do Galicji, na ziemiach Królestwa Polskiego kolportowano w całym okresie pierwszej wojny światowej tylko jedno czasopismo pedagogiczne, początkowo pod tytułem „Wychowanie w Domu i Szkole” (od 1908 r.) , a od 1916 r. pod nazwą „Przegląd Pedagogiczny”, któremu patronowało Stowarzyszenie Nauczycielstwa Polskiego ${ }^{9}$. Z prawnego punktu widzenia było ono kontynuacją ukazującego się od 1882 do 1905 r. „Przeglądu Pedagogicznego”, a następnie „Szkoły Polskiej” (1906-1907) i „Spraw Szkolnych” (1908). W przygotowywanych każdego roku dziesięciu zeszytach swoje poglądy w dziale naukowo-pedagogicznym prezentowali najczęściej: Aniela Szycówna, Stanisław Kopczyński, Jadwiga Dynowska, Maksymilian Bienenstock, Teodora Męczkowska, Stanisław Szober, Konrad Chmielewski, Mikołaj Wisznicki, Józef Szwemin, Wiktor Wąsik, Kazimierz Lutosławski. Oprócz rozpraw wspomnianych autorów, którzy przekazywali wiedzę z psychologii i pedagogiki dziecka, historii wychowania oraz dydaktyk szczegółowych, a także metodyki wychowania domowego, szkolnego i pozaszkolnego (np. Szycówna 1914: 50-56, 478-483; Kopczyński 1914: 108-116; Dynowska (1914): 203-231, 305-337, 444-460; Męczkowska 1918: 13-19; Szober 1917: 37-44), umieszczano w nich rubryki sprawozdawczo-informacyjne, na które składały się relacje z ruchu pedagogicznego w kraju i za granicą oraz raporty z funkcjonowania szkolnictwa ludowego, wiadomości ze zjazdów oświatowych, krytyczne oceny rozpraw o wychowaniu i nauczaniu oraz podręczników szkolnych, doniesienia z działalności stowarzyszeń nauczycielskich, korespondencje z rodzicami i wychowawcami oraz materiały do pogadanek z dziećmi.

O ile powyższe czasopisma pedagogiczne kierowano do czytelników z danego zaboru, a nawet do abonentów poza jego granicami, o tyle wychodzący w Lublinie

\footnotetext{
${ }^{9}$ Stowarzyszenie Nauczycielstwa Polskiego powstało w 1905 r., a w 1919 r. połączyło się z galicyjskim Towarzystwem Nauczycieli Szkół Wyższych.
} 
w latach 1916-1918 dwutygodnik oddziału regionalnego Stowarzyszenia Nauczycielstwa Polskiego „Szkoła Polska”, który redagował Stefan Plewiński, adresowano do miejscowego odbiorcy, choć zdarzało się, że trafiał on również do zainteresowanych w innych rejonach Królestwa Polskiego. W pierwszym numerze, który opuścił drukarnię pod koniec maja 1916 r., zamieszczono patetyczną deklarację programową, w której między innymi napisano:

Z dymem pożarów, z kurzem krwi bratniej powstaje Polska do nowego życia. Bez względu na to, jak się ułożą nasze warunki polityczne, bez względu na to, gdzie staną nasze słupy graniczne, nie oglądając się na mniejszą lub większą życzliwość dla sprawy naszej wolnych narodów, a biorąc pod uwagę tylko własne materialne i moralne zasoby, przejawiające się w nas prawo do życia, słowem, trzeźwo rozważając sprawę naszego bytu narodowego, możemy śmiało i z ufnością spoglądać w przyszłość. (...) Dzisiaj, z wiarą, że służymy dobrej sprawie, w imię Boże puszczamy w świat ten pierwszy numer naszego wydawnictwa, które stojąc na stanowisku pielęgnowania naszych pięknych tradycji narodowych, dążyć będzie jednocześnie do tępienia przez wychowanie tych wad narodowych, które przekazała nam historia Polski niepodległej, i tych, które powstały w okresie niewoli (F. K. 1916: 8-9).

Pozostając w zgodzie z powyższym przesłaniem, każdy numer „Szkoły Polskiej" otwierały artykuły autorstwa uznanych publicystów, m.in. Jana Żywara, ks. Jana Kureczko, Wincentego Sierakowskiego, Henryka Rowida, Wacława Jasińskiego, Józefa Ciembroniewicza, Ignacego Chrzanowskiego, Ludwika Jaxy-Bykowskiego i Ferdynanda Śliwińskiego, którzy rozważali o różnych aspektach wychowania $\mathrm{w}$ duchu narodowym, metodach i środkach dydaktycznych, organizowaniu i przeprowadzaniu lekcji z historii literatury polskiej, ujednoliceniu polskiej pisowni, nowoczesnym przygotowaniu kandydatów do zawodu nauczycielskiego (Michalska 2019: 77-85). Dział pod nazwą Kronika Pedagogiczna przynosił z kolei informacje o konferencjach i zjazdach pedagogicznych, podręcznikach dla szkół początkowych, kursach uzupełniających dla nauczycieli, działalności organizacji oświatowych i związków nauczycielskich, wynagradzaniu za pracę w szkole. Kolejne karty przeznaczano na recenzje nowo wydanych książek psychologicznych, pedagogicznych i metodycznych, a także z historii Polski. Całkowicie oddzielną kolumnę stanowił przekaz dotyczący aktywności lubelskiego oddziału Stowarzyszenia Nauczycielstwa Polskiego.

Podobnie lokalny charakter miał wydawany w Cieszynie od 1892 r. „Miesięcznik Pedagogiczny". Ponieważ w 1902 r. pismo to zostało organem miejscowego Polskiego Towarzystwa Pedagogicznego ${ }^{10}$, najwięcej w nim miejsca poświęcano

\footnotetext{
${ }^{10}$ Polskie Towarzystwo Pedagogiczne w Cieszynie powstało w 1895 r. W 1925 r. połączyło się ze Związkiem Polskiego Nauczycielstwa Szkół Powszechnych.
} 
działalności tej organizacji. Nie oznaczało to jednak, że nie przywiązywano znaczenia do publikacji na tematy dotyczące wychowania i nauczania, ustroju szkolnictwa, kształcenia nauczycieli szkół ludowych. Trzeba jednak zauważyć, że w okresie wojny opracowań z tego zakresu zamieszczano niewiele, ponieważ w poszczególnych latach wydawano rocznie tylko dwa zeszyty, których objętość równała się liczbie stron jednego miesięcznego numeru kolportowanego jeszcze przed wojną. Można domniemywać, że ówczesny redaktor Paweł Bobek zmagał się nie tylko z kłopotami natury finansowej i niezliczonymi przeszkodami ze strony firm drukarskich, ale także $\mathrm{z}$ trudnościami zaangażowania odpowiednio kompetentnych autorów, o czym mogą świadczyć jego wypowiedzi, w których wskazywał, że większość publicystów została wcielona do wojska, a niektórzy spośród nich polegli w walkach (Od redakcji 1916: 77; Dwudziestopięciolecie... 1917: 2; Pasek 1975: 299). Pomimo dramaturgii ówczesnych wydarzeń nie dopuścił jednak do zawieszenia pisma, uzasadniając swój punkt widzenia słowami:

Ale nie tylko przygnębienie płynie $\mathrm{z}$ dni obecnych. $\mathrm{Z}$ wiru tych walk i okropności wojny (...) już dziś wyczuć można świeży powiew nowych idei (...) że wreszcie narodowi naszemu będzie danem samemu stanowić o sobie (...) że nastaną czasy, gdy polska szkoła ludowa zakwitnie na wszystkich ziemiach polskich...(Zmartwychwstanie 1915: 8).

Postanowienie o kontynuowaniu edycji „Miesięcznika Pedagogicznego” zdecydowanie wymusiło wprowadzenie w nim istotnych zmian dotyczących rodzajów publikowanych materiałów. Kosztem powiększenia rubryk mających charakter wyłącznie informacyjny i sprawozdawczy: Z literatury pedagogicznej, $Z$ prasy, Z kraju, Z ziemi polskiej, Sprawy różne w poważnym stopniu zrezygnowano z umieszczania tekstów o wydźwięku naukowym. W omawianym okresie wydrukowano ich zaledwie kilka i poświęcono myśli pedagogicznej, konieczności upaństwowienia szkolnictwa ludowego i reformie seminariów nauczycielskich, metodyce nauczania historii oraz nowożytnej dydaktyce przyrody, a także problemowi moralnie negatywnego wpływu filmu na młodzież (Badura 1914: 164-170; Bobek 1914: 170-179, 198-203; Sierakowski 1916a: 14-16; Sierakowski 1916b: 18-21; Wajdowicz (1917): 4-10; Bobek 1917a: 11-13; Bobek 1917b: 40-42).

Podsumowując, należy stwierdzić, że u progu niepodległości Polski, niezależnie od terytorialnego umiejscowienia, redakcje czasopism pedagogicznych organizacji nauczycielskich nie tylko potrafiły ponad podziałami dzielnicowymi skupić wokół siebie profesjonalnie przygotowanych autorów, którzy w formie przystępnej narracji upowszechniali wiedzę naukową z różnych rejonów nauk o wychowaniu, ale także zdołały zachęcić do wzajemnej pomocy i współpracy reporterskiej liczną grupę społeczników Królestwa Polskiego i Galicji, dzięki czemu czytelnicy na bieżąco otrzymywali wiadomości o sytuacji szkolnictwa na tych ziemiach oraz o przebiegu i wynikach prowadzonych tam debat nad przyszłością szkolnictwa i wychowania w wolnym już od zaborców kraju. 


\section{Bibliografia}

Badura J. (1914) Wychowanie społeczne. Teoretycy: Foerster i Kerschensteiner, „Miesięcznik Pedagogiczny", nr 7-8, s. 164-170.

Bobek P. (1914) Uwagi o nauce historii w szkole ludowej, „Miesięcznik Pedagogiczny”, nr 7-8, s. 170-179; nr 9-10, s. 198-203.

Bobek P. (1917a) Na temat specjalnej metodyki nauki historii, „Miesięcznik Pedagogiczny", nr 1-3, s. 11-13.

Bobek P. (1917b) Około reformy seminariów nauczycielskich, „Miesięcznik Pedagogiczny", nr 4-12, s. 40-42.

Bienenstock M. (1914) Wychowanie estetyczne w świetle teorii Fr. W. Foerstera, „Muzeum", t. I, z. 1-2, s. 43-58; z. 3, s. 191-197; z. 4, s. 352-361.

Buciewicz J. (1914) Uwagi o praktycznej nauce gospodarstwa domowego dla dziewcząt w szkołach ludowych wiejskich i małomiasteczkowych, „Szkoła”, s. 133-138.

Chwila obecna (1916), „Szkoła Polska”, nr 1, s. 1-2.

Chmielewski K. (1917) Program nauki o Polsce współczesnej, „Muzeum”, z. 2, s. 273-275.

Dynowska J. (1914) O zabawie, „Wychowanie w Domu i Szkole”, nr 3, s. 203-231; nr 4, s. 305-337; nr 5, s. 444-460.

Dwudziestopięciolecie „Mies. Pedagogicznego” (1917), „Miesięcznik Pedagogiczny”, nr 1-3, s. 2 .

Dzieci szkolne wielkiej Warszawy (1918), „Szkoła”, nr 8-9, s. 250.

Falski M. (1917) Drogi postępu w metodyce nauczania liter, „Ruch Pedagogiczny”, nr 3, s. 49-54; nr 4, s. 75-79; nr 5, s. 114-120.

Feliński G. (1917) Kilka myśli o ustroju przyszłej szkoły polskiej, „Muzeum”, z. 3, s. 321-348.

Filipowicz F. (1986) Narodziny ruchu w: Zwiq̨zek Nauczycielstwa Polskiego. Zarys dziejów 1905-1985, B. Grześ (red.), Warszawa, Instytut Wydawniczy Związków Zawodowych, s. 39-98.

F. K. (1916) Do pracy, „Szkoła Polska”, nr 1, s. 8-9.

Halban A. (1914) O krytyce szkolnictwa średniego, „Muzeum”, t. II, z. 1, s. 7-20. 
Hauswald E. (1917) Sprawa przygotowania młodzieży w szkołach średnich, „Muzeum”, z. 3, s. 317-321.

Ika (1914) Odrodzenie seminariów nauczycielskich w Stanach Zjednoczonych, „Szkoła”, nr 4, s. 145-146.

Jamrożek W. (2015) Kongresy i zjazdy pedagogiczne w rozwoju polskiej myśli i praktyki edukacyjnej (do 1939 roku), Poznań, Wydawnictwo Naukowe Uniwersytetu Adama Mickiewicza, s. 28-62.

Jaxa-Bykowski L. (1916) Klasy skombinowane, „Muzeum”, z. 2-3, s. 42-46.

Kielski B. (1917) Główne problemy polskiego szkolnictwa średniego (Zarys programu prac), „Muzeum”, z. 6, s. 511-525.

Kopczyński S. (1914) Przyczynek do badań psychologicznych nad młodzieżq̨ szkolnq, „Wychowanie w Domu i Szkole”, nr 2, s. 108-116.

Kornecki J. (1914) Stanowisko społeczne nauczyciela Polaka, „Szkoła”, s. 94-96.

Kretz J. (1918) Rozważania na pedagogikq naukowq, „Ruch Pedagogiczny”, nr 8-10, s. $173-182$.

Kurpiel M. A. (1916) Zadania szkoły średniej w chwili obecnej, „Muzeum”, z. 6, s. 219-229.

Laskowiczówna M. (1914) Nowe prądy metodyczne, „Ruch Pedagogiczny”, nr 3, s. $47-52 ; \mathrm{nr} 4$, s. $65-70$.

Michalska I. (2019) W oczekiwaniu na niepodległość. Stanowisko lubelskiej „Szkoły Polskiej” (1916-1918) wobec edukacji narodowej, „Studia Edukacyjne”, nr 53, s. 77-85.

Męczkowska T. (1918) Znaczenie wychowawcze nauki szkolnej, „Wychowanie w Domu i Szkole", nr 1, s. 13-19.

Na przełomie (1916), „Muzeum”, z. 1, s. 1-2.

Nasze dq̨żenia i cele (1917), „Ruch Pedagogiczny”, nr 1-2, s. 3.

Nittman K. I. (1914-1915) Szkoła pracy w Niemczech, „Szkoła”, nr 7-8, s. 317-338; nr 9-10, s. 443-461.

Od Redakcyi (1912), „Ruch Pedagogiczny”, nr 1-2, s. 2.

Od Redakcyi (1916), „Miesięcznik Pedagogiczny”, nr 8-12, s. 77. 
Odrzywolski M. (1917) Cel i granice eksperymentu w pedagogice, „Muzeum”, z. 2, s. $118-130,185-189$.

Odrzywolski M. (1917) Typy uwagi u młodzieży szkolnej, „Muzeum”, z. 1, s. 5-28.

O uniwersytet polski w zaborze rosyjskim (1916), „Szkoła”, nr 3, s. 98.

Pasek E. (1975) „Miesięcznik Pedagogiczny” - czasopismo nauczycielskie w latach 1892-1939, „Przegląd Historyczno-Oświatowy”, nr 2, s. 299.

Podgórska E. (1973) Krajowy Zwiq̨zek Nauczycielstwa Ludowego w Galicji 1905-1918, Warszawa, Nasza Księgarnia, s. 148.

Przeniosło M. (2015) Polskie towarzystwo Pedagogiczne we Lwowie (materiały z lwowskiego Archiwum Historycznego), „Galicja. Studia i Materiały”, nr 1, s. 379.

Rowid H. (1914) Jan Władysław Dawid, „Ruch Pedagogiczny”, nr 1-2, s. 1-9.

Rowid H. (1917) Podstawy pedagogiki Trentowskiego, „Ruch Pedagogiczny”, nr 3, s. 41-47; nr 4, s. 65-70; nr 5, s. 89-96; nr 6, s. 129-135; nr 7, s. 153-159; nr 8, s. $177-182$.

Rowid H. (1917) Samorzq̨d uczniów w szkole, „Ruch Pedagogiczny”, nr 1-2, s. 12-13.

Rowid H. (1918) Nowa era w wychowaniu, „Ruch Pedagogiczny”, nr 1-2, s. 1-9.

Rowid H. (1918) Odrodzenie szkoły polskiej, „Ruch Pedagogiczny”, nr 8-10, s. $169-173$.

Ruch oświatowy w Królestwie Polskim i na Litwie (1916), „Muzeum”, z. 1, s. 13; z. 2-3, s. 58-60.

Siciński M. (1914) Potrzeby szkół przemysłowych uzupełniających we Lwowie, „Szkoła”, s. 122-132.

Sierakowski W. (1916a) Kinoteatr a młodzież, „Miesięcznik Pedagogiczny”, nr 1-17, s. 17-18.

Sierakowski W. (1916b) Uwagi na temat upaństwowienia seminariów nauczycielskich, „Miesięcznik Pedagogiczny”, nr 1-7, s. 18-21.

Skoczylas L. (1914) Wychowawca narodowy, „Szkoła”, s. 309-312, 438-443.

Sławomirski B. (1918) Nauka geografii w przyszłej szkole powszechnej, względnie w niższej szkole średniej, „Ruch Pedagogiczny”, nr 6, s. 118-127. 
Słowo od redaktora (1912), „Ruch Pedagogiczny”, nr 1, s. 2.

Sprawy szkolne na ziemiach zajętych przez armię niemieckq (1916), „Szkoła”, nr 1-2, s. $45-51$.

Stachoń L. (1917) Stan szkolnictwa początkowego i średniego w Królestwie Polskim, „Szkoła”, nr 2-5, s. 76-80.

Stan obecny szkolnictwa w Królestwie Polskim (1916), „Szkoła”, nr 1-2, s. 41-45.

Stan szkolnictwa w miastach Królestwa Polskiego (1918), „Szkoła”, nr 8-9, s. 251-252.

Stopińska-Pająk A. (1996) Wkład czasopisma „Szkoła” w rozwój myśli pedagogicznej w: Myśl edukacyjna w Galicji 1772-1918: ciagłość zmiana, Cz. Majorek, A. Meissner (red.), Rzeszów, Wydawnictwo Wyższej Szkoły Pedagogicznej, s. 171-174.

Stypiński J. (1917) Nauczycielstwo polskie w Królestwie, „Muzeum”, z. 2, s. 267-273.

Szajowski E. (1914) W sprawie reformy szkolnictwa: I Memoryał Uniwersytetu Jagiellońskiego, „Szkoła”, s. 213-220.

Szkolnictwo rolnicze w Królestwie (1917), „Szkoła”, nr 9-10, s. 343.

Szober S. (1917) Ujednostajnienie pisowni polskiej, „Wychowanie w Domu i Szkole”, nr 1-2, s. 37-44.

Szulakiewicz W. (2013) O zasłużonych redaktorach czasopisma „Muzeum” 1885-1939, w: Addenda do dziejów oświaty. Z badań nad prasq XIX i początków XX wieku, I. Michalska, G. Michalski (red.), Łódź, Wydawnictwo Uniwersytetu Łódzkiego, s. 108.

Szycówna A. (1914) Badania pojęć moralnych i charakteru dziecięcego, „Wychowanie w Domu i Szkole", nr 5, s. 478-483.

Szycówna A. (1914) Dr Marya Montessori. Domy dziecięce, „Muzeum”, t. I, z. 1-2, s. 98-105.

Szycówna A. (1914) Różnice umysłowości chłopców i dziewczq̨t, „Wychowanie w Domu i Szkole", nr 1, s. 50-56.

Szycówna A. (1914-1915) Jan Władysław Dawid jako pedagog i psycholog, „Muzeum”, t. II, z. 3, s. 182-191.

Turowski S. (1914) Psychologia eksperymentalna w szkole, „Muzeum”, t. I, z. 1-2, s. 59-81; z. 3, s. 198-217; z. 4, s. 361-376; z. 5, s. 518-537. 
Wajdowicz W. (1917) Zasadnicze hasła nowożytnej dydaktyki przyrodniczej, „Miesięcznik Pedagogiczny", nr 1-3, s. 4-10.

Wacek R. (1914-1915) Wychowanie fizyczne młodzieży w zimie, „Muzeum”, t. II, z. 2, s. $140-144$.

W. B. (1914) W sprawie reformy seminariów nauczycielskich, „Szkoła”, s. 180-185, 234-242.

Witkowska H. (1917) O nauczaniu historii, „Ruch Pedagogiczny”, nr 9-10, s. 183-188.

Wojtyński W. (1965) Ruch Pedagogiczny od swego powstania w roku 1912 do chwili obecnej, „Ruch Pedagogiczny”, nr 5/6, s. 22.

Zaproszenie (1868), „Szkoła”, nr 1, s. 64.

Ze szkolnictwa Królestwa Polskiego (1917), „Muzeum”, z. 6, s. 559-561.

Z nowym rokiem (1910), „Szkoła”, nr 1, s. 5.

Zawiliński R. (1917) Ustrój przyszłej szkoły polskiej, „Muzeum”, z. 2, s. 258-267.

Zmartwychwstanie (1915), „Miesięcznik Pedagogiczny”, nr 1-4, s. 8. 